\title{
Pengaruh Pendidikan dan Pengalaman Kerja Terhadap Kinerja Pegawai di Kantor Camat Tungkal Ilir Kabupaten Tanjung Jabung Barat
}

\author{
Saiyid Syekh \\ Fakultas Ekonomi, Universitas Batanghari Jambi, Indonesia
}

\begin{abstract}
Tungkal Ilir Sub District is one of the existing sub district in the regency administration of Tanjung Jabung Barat with an area of 100,31 $\mathrm{km}^{2}$. Sub-district office Tungkal Ilir, Tanjung Jabung Barat regency is located in the middle of Kuala Tungkal City and shelter 10 vilages. Based on linear regression analysis results show the equation $Y$ $=a+b 1 x 1+b 2 x 2+e$ with $F$ tests the value of 0.001, a value of the t test for education and the value of $0.023 t$ test for the work experience of 0.001 . Rated $R$ square $29.3 \% 70.7 \%$, while the rest describes other factors outside the model study and the value of $R$ 0542, which means the correlation is being. The suggestion for a new researcher is hoped to use a most recent year and the interval years for the research in order the reaserch could describe a detail information about education and work experience.
\end{abstract}

Keyword : Education and Work Experience

\section{PENDAHULUAN}

Sumber daya manusia berperanan penting dalam aktivitas suatu instansi, karena bagaimanapun kemajuan dan keberhasilan sebuah instansi tidak terlepas dari peranan dan kemampuan sumber daya manusia yang sangat baik dan juga berdedikasi tinggi yang mencurahkan seluruh keampuannya dalam bekerja, dengan tersedianya sumber daya manusia yang berkualitas itu adalah suatu asset yang tidak ternilai bagi suatu instansi. Pendidikan sangat erat kaitannya dengan proses pembelajaran, melalui proses dan prosedur yang sistematis yang terorganisir baik teknis maupun manajerial yang berlangsung dalam waktu yang relatif lama. Sedangkan pengalaman kerja berkaitan dengan jenis pekerjaan atau jabatan yang pernah diemban oleh seseorang, serta lamanya mereka bekerja pada masing-masing pekerjaan. Dengan pengalaman kerja maka akan lebih mudah melaksanakan pekerjaan. Jika kita bandingkan pegawai baru dengan pegawai lama maka sudah pasti pegawai lama lebih unggul, karena semakin banyak pengalaman kerja seseorang maka akan semakin berdampak pada luasnya wawasan pengetahuan dibidang pekerjaanya serta akan meningkatkan keterampilannya. (Adisetiawan, 2017)

Kecamatan yang merupakan pusat pimpinan pemerintahnya adalah kantor Camat yang dipimpin oleh seorang Camat merupakan lembaga pamerintah daerah yang bertugas mengatur dan melayani masyarakatnya dibidang kepemerintahan. Untuk melayani masyarakat dengan baik dan memuaskan maka para pegawai kantor Camat harus memiliki pendidikan serta pengalaman yang sesuai dengan bidang kerja yang diberikan, karena suatu pekerjaan yang dilakukan oleh seorang yang tidak sesuai dengan bidangnya maka pekerjaan itu tidak akan baik dan sukses. Pendidikan berfungsi sebagai penggerak sekaligus penentu terhadap potensi kemampuan pegawai dalam meningkatkan kinerjanya. Sedangkan pengalaman kerja akan mempengaruhi keterampilan kerja dalam melaksanakan tugas dan dapat membuat kerja lebih efektif. Dengan demikian pendidikan dan pengalaman yang sudah di dapat oleh para pegawai yang ada di kantor Camat Tungkal Ilir diharapkan mampu membuat kinerja mereka dalam hal administrasi maupun pelayanan publik dapat lebih baik dari sebelumnya. Salah satu hal yang biasanya digunakan untuk mengukur kemampuan seorang pegawai adalah dari latar belakang pendidikanya, di samping dari kemampuan dalam melaksanakan tugas dan kewajibanya. Adapun jumlah pegawai pada kantor Camat Tungkal Ilir Kab. Tanjab Barat tahun 2013 - 2017 menurut klasifikasi pendidikan dapat dilihat pada Tabel 1 berikut: 
Tabel 1

Jumlah Pegawai Pada Kantor Camat Tungkal Ilir Kab. Tanjab Barat Menurut Tingkat

PendidikanTahun 2013-2017

\begin{tabular}{cccrrrr}
\hline \multirow{2}{*}{ Tahun } & \multicolumn{2}{c}{ Jumlah Pegawai (Orang) } & & \multirow{2}{*}{ Total } & perkembangan \% \\
& SMA & DIII & S1 & & \\
2013 & 24 & 2 & 9 & 35 & 5,71 \\
2014 & 22 & 1 & 10 & 33 & 6,06 \\
2015 & 25 & 1 & 9 & 35 & 17,14 \\
2016 & 28 & 3 & 9 & 41 & 7,31 \\
2017 & 31 & 3 & 10 & 44 & \\
\hline
\end{tabular}

Sumber : Kantor Camat Tungkal Ilir, 2018

Berdasarkan tabel diatas diketahui bahwa jumlah pegawai pada kantor Camat Tungkal Ilir Kab. Tanjab Barat berdasarkan tingkat pendidikan dalam lima tahun terakhir dilihat dari persentase dari tahun 2013-2014 tidak mengalami perkembangan, dan pada tahun 2016 jumlah pegawai mengalami perkembangan yang paling besar yaitu sebesar 17,14\%, di ikuti pada tahun 2017 sebesar 7,31\% dan perkembangan yang terendah yaitu tahun 2015 yaitu sebesar $6,06 \%$.

Tabel 2

Jumlah Pegawai Pada Kantor Camat Tungkal Ilir Kab. Tanjab Barat Menurut Pengalaman Kerja Tahun 2013-2017

\begin{tabular}{lrrrrr}
\hline \multirow{2}{*}{ Tahun } & \multicolumn{2}{c}{ Jumlah Pegawai (orang) } & & TOTAL \\
& $1-4$ tahun & $5-9$ tahun & $10-15$ tahun & 9 & 15 tahun \\
2013 & 2 & 9 & 10 & 12 & 35 \\
2014 & 2 & 9 & 11 & 13 & 33 \\
2015 & 1 & 10 & 10 & 15 & 35 \\
2016 & 6 & 10 & 8 & 17 \\
2017 & 9 & 10 & & 41 \\
\hline
\end{tabular}

Sumber : Kantor Camat Tungkal Ilir, 2018

Berdasarkan tabel di atas diketahuai bahwa pengalaman kerja pegawai pada kantor Camat Tungkal Ilir Kab. Tanjab Barat dalam lima tahun terakhir terbanyak yaitu $>15$ tahun sebesar 38,30\%, 10-15 tahun dan 5-9 tahun sebesar 25,53\% dan 1-4 tahun sebesar 10,64\%. Dimensi kinerja mencakup semua unsur yang ada akan dievaluasi dalam pekerjaan masing-masing pegawai. Dimensi ini mencakup berbagai kriteria yang sesuai untuk digunakan mengukur hasil pekerjaan yang telah diselesaikan. Pada umumnya cara peniaian kinerja mempertimbangkan hal-hal sebagai berikut : kuantitas (jumlah yang harus diselesaikan), kualitas (mutu yang dihasilkan) serta ketepatan waktu (kesesuaian dengan waktu yang telah direncanakan). Hasil kinerja Camat Tungkal Ilir Kab. Tanjab Barat, bisa kita lihat pada tabel di bawah ini :

Tabel 3

Perkembangan Target dan Realisasi Pelayanan Publik Pada Kantor Camat Tungkal Ilir Kab. Tanjab Barat Tahun 2013-2017

\begin{tabular}{|c|c|c|c|c|c|}
\hline No & Tahun & Program kerja & Target & Terealisasi & Persentase \% \\
\hline \multirow{5}{*}{1} & 2013 & \multirow{5}{*}{$\begin{array}{l}\text { KK } \\
\text { (Surat) }\end{array}$} & 1.510 & 1.472 & 97,48 \\
\hline & 2014 & & 1.815 & 1.704 & 93,88 \\
\hline & 2015 & & 1.956 & 1.728 & 88,34 \\
\hline & 2016 & & 1.970 & 1.816 & 90,18 \\
\hline & 2017 & & 2.050 & 1.792 & 87,41 \\
\hline \multirow{5}{*}{2} & 2013 & \multirow{5}{*}{$\begin{array}{l}\text { SITU } \\
\text { (Surat) }\end{array}$} & 195 & 158 & 81,02 \\
\hline & 2014 & & 310 & 302 & 97,41 \\
\hline & 2015 & & 398 & 355 & 89,19 \\
\hline & 2016 & & 431 & 374 & 86,77 \\
\hline & 2017 & & 513 & 447 & 92,98 \\
\hline 3 & 2013 & IMB & 185 & 173 & 93,51 \\
\hline
\end{tabular}




\begin{tabular}{|c|c|c|c|}
\hline (Surat) & 190 & 140 & 73,68 \\
\hline 2015 & 216 & 180 & 83,33 \\
\hline 2016 & 227 & 207 & 91,18 \\
\hline 2017 & 252 & 234 & 92,85 \\
\hline
\end{tabular}

Sumber : Kantor Camat Tungkal Ilir, 2018

Keterangan; KK : Kartu Keluarga; SITU : Surat Izin Tanda Usaha; IMB : Izin Mendirikan Bangunan

Berdasarkan tabel diatas diketahui bahwa masih terdapat program kerja yang belum tercapai sesuai dengan target yang diharapkan dalam lima tahun terakhir realisasi pembuatan KK sebesar 91,45\%, SITU sebesar 89,47\% dan IMB sebesar 86,91\%. Adapun tujuan penelitian ini adalah menganalisis pengaruh pendidikan dan pengalaman kerja terhadap kinerja pegawai di Kantor Camat Tungkal Ilir Kab. Tanjab Barat.

\section{Tinjauan Pustaka}

\section{Pengertian Pendidikan}

Pengertian pendidikan menurut Tirtarahardja (2005) adalah usaha sadar dan terencana untuk mewujudkan suasana belajar dan proses pembelajaran agar peserta didik secara aktif mengembangkan potensi dirinya untuk memiliki kekuatan spiritual keagamaan, pengendalian diri, kepribadian, kecerdasan, akhlak mulia, serta keterampilan yang diperlukan dirinya dan masyarakat. Pendidikan sebagai obyek dan juga subyek pembangunan perlu diperhatikan karna pendidikan merupakan penggerak utama dari pembangunan. Tingkat atau jenjang pendidikan adalah tahapan pendidikan yang ditetapkan berdasarkan tingkat perkembangan peserta didik, tujuan yang akan dicapai, dan kemampuan yang dikembangkan. Menurut Undang-Undang RI Nomor 20 Tahun 2003 tentang Sistem Pendidikan Nasional. Pendidikan Nasional berfungsi mengembangkan kemampuan dan membentuk watak serta peradaban bangsa yang bermartabat dalam rangka mencerdaskan kehidupan bangsa, bertujuan untuk berkembangnya potensi peserta didik agar menjadi manusia yang beriman dan bertaqwa kepada Tuhan Yang Maha Esa, berakhlak mulia, sehat, berilmu, cakap, kreatif, mandiri, dan menjadi warga Negara yang yang demokratis serta bertanggung jawab.

\section{Jenis-jenis Pendidikan}

Menurut undang-undang RI Nomor 2 Tahun 1989, pendidikan dilaksanakan melalui dua jalur yaitu jalur formal dan non formal yang dapat diketegorikan menjadi tiga yakni: (1) pendidikan formal, yaitu jalur pendidikan yang terstruktur dan berjenjang yang terdiri atas pendidikan dasar, pendidikan menengah, dan pendidikan tinggi; (2) pendidikan informal, yaitu proses yang berlangsung sepanjang usia sehingga setiap orang memperoleh nilai, sikap keterampilan dan pengetahuan yang bersumber dari pengalaman hidup sehari-hari; dan (3) pendidikan non formal, yaitu jalur pendidikan di luar pendidikan formal yang dapat dilaksanakan secara terstruktur dan berjenjang. Sedangkan Tirtarahardja (2005), menyebutkan indikator tingkat pendidikan yaitu terdiri dari : (1) Jenjang pendidikan, adalah tahapan pendidikan yang ditetapkan berdasarkan tingkat perkembangan peserta didik, tujuan yang akan dicapai dan kemampuan yang dikembangkan; (2) kesesuaian jurusan, adalah sebelum karyawan direkrut terlebih dahulu perusahaan menganalisis tingkat pendidikan dan kesesuaian jurusan pendidikan pegawai tersebut agar nantinya dapat ditempatkan pada posisi jabatan yang sesuai dengan kualifikasi pendidikan; dan (3) kompetensi, adalah pengetahuan, penguasaan terhadap tugas, keterampilan dan nilai-nilai dasar yang direfleksikan dalam kebiasaan berpikir dan bertindak. (Adisetiawan, 2016)

\section{Faktor-faktor yang mempengaruhi pendidikan}

Adapun faktor-faktor yang mempengaruhi pendidikan terdiri atas (Tirtarahardja, 2005): (1) Faktor Tujuan, merupakan faktor yang terpenting di dalam pendidikan untuk diarahkan kemana anak-anak yang kita didik ini, tergantung daripada tujuan pendidikan; (2) Faktor Anak Didik, tingkat pendidikan anak ditinjau dari segi pedagogi; (3) Faktor Pendidik; (4) Faktor Alat 


\section{Pengalaman Kerja}

Menurut Foster (2001), pengalaman kerja adalah sebagai suatu ukuran tentang lama waktu atau masa kerjanya yang telah ditempuh seseorang dalam memahami tugas-tugas suatu pekerjaan dan telah melaksanakannya dengan baik. Pengalaman kerja akan dapat memberikan keuntungan bagi seseorang dalam melaksanakan kerja selanjutnya karena setidaknya orang tersebut sudah pernah melakukan pekerjaan itu sehingga ia akan tahu tentang pekerjaan yang akan dihadapi. Berdasarkan pengertian yang terdapat dalam Kamus Besar Bahasa Indonesia (Depdiknas, 2005), pengalaman merupakan merupakan segala sesuatu yang pernah dialami (dijalani, dirasai, ditanggung), sedangkan kerja merupakan kegiatan melakukan sesuatu. Maka dapat diketahui bahwa pengalaman kerja merupakan kegiatan melakukan segala sesuatu yang pernah dialami oleh seseorang. Pengalaman kerja adalah tingkat pengetahuan serta keterampilan seseoarang yang dapat diukur dari masa kerja seseorang. Sehingga semakin lama seseorang bekerja semakin bertambah pengalaman terhadap pekerjaannya. Dengan bnyaknya pengalaman kerja yang dimiliki seseorang pekerja maka orang tersebut akan lebih menguasai pekerjaannya, sehingga dapat menyelesaikan pekerjaannya dengan baik ini berarti orang tersebut mempunyai efektivitas kerja yang baik. Selain itu juga pengalaman kerja yang akan ikut mematangkan orang yang bersangkutan dalam menghadapi tugas-tugas manajerial yang akan dijalaninya.

\section{Kinerja Pegawai}

Kinerja sebagai hasil usaha seseorang yang memiliki kemampuan dan perbuatan dalam situasi tertentu. Kinerja perorangan mempunyai hubungan yang eratdengan kinerja lembaga atau perusahaan. Dengan kata lain kinerja seseorang tinggi apabila dia mempunyai keahlian yang tinggi, bersedia bekerja sesuai dengan upah atau gaji yang telah disepakati. Agar seseorang dapat mencapai kinerja yang tinggi tergantung pada kerjasama, kepribadian, kepandaian yang beranekaragam, kepemimpinan, keselamatan, pengetahuan pekerjaan, kehadiran, kesetiaan, ketangguhan dan inisiatif. Untuk membahas kinerja, maka harus diketahui arti dari masing-masing kata tersebut. Kinerja merupakan prilaku yang nyata yang ditampilkan setiap orang sebagai prestasi kerja yang dihasilkan oleh pegawai sesuai dengan perannya dalam organisasi. (Rivai 2004). Menurut Kaswan (2012) ada 6 kriteria utama yang digunakan dalam menilai kinerja yaitu : (1) Kualitas, seberapa jauh atau baik proses atau hasil menjalankan aktivitas mendekati kesempurnaan ditinjau dari kesesuaian dengan cara ideal menjalankan suatu kegiatan atau memenuhi tujuan yang dikehendaki oleh aktivitas suatu usaha; (2) Kuantitas, jumlah yang dihasilkan, dinyatakan dalam nilai, jumlah unit atau jumlah siklus kegiatan yang telah diselesaikan; (3) Ketepatan waktu, seberapa jauh dan baik sebuah aktivitas diselesaikan, atau hasil yang diproduksi pada waktu yang paling awal yang dikehendaki dari sudut pandang koordinasi dengan output yang lain maupun memaksimumkan waktu yang ada untuk kegiatan-kegiatan lain; (4) efektivitas biaya, seberapa baik atau jauh sumber daya organisasi misalnya manusia, teknologi dan bahan, dimaksimumkan dalam pengertian memperoleh keuntungan tertinggi atau pengurangan dalam kerugian dari masing-masing unit atau contoh penggunaan sumber daya; (5) Kebutuhan untuk supervisi, seberapa jauh atau baik seorang karyawan dapat melaksanakan fungsi kerja tanpa harus meminta bantuan pengawas atau memerlukan intervensi pengawasan untuk mencegah hasil yang merugikan; dan (6) dampak interpersonal, seberapa jauh baik karyawan meningkatkan harga diri, itikad baik (goodwill) dan kerjasama antara sesama karyawan dan bawahan.

\section{Hipotesis}

Hipotesis dalam penelitian ini adalah: diduga pendidikan dan pengalaman kerja berpengaruh signifikan terhadap kinerja pegawai di kantor Camat Tungkal Ilir Kabupaten Tanjung Jabung Barat.

\section{METODE PENELITIAN}

Metodologi penelitian yang akan digunakan dalam penelitian ini adalah menggunakan penelitian kuantitatif. Penelitian kuantitatif adalah penelitian yang menekankan pada pengujian teori-teori melalui pengungkapan variabel-variabel penelitian dengan angka dan melakukan analisa data dengan prosedur statistik. Penelitian yang dilakukan melalui teknik observasi dengan melakukan pengamatan langsung 
terhadap kegiatan pegawai kantor Camat Tungkal Ilir Kab. Tanjab Barat serta melakukan wawancara kepada mereka untuk mendapatkan informasi.

\section{Metode Analisis}

Pengukuran masing-masing indikator pendidikan dan pengalaman kerja terhadap kinerja di atas dengan menggunakan analisis deskriftif dengan menggunakan pendekatan nilai interval skala pengukuran. Untuk menghitung pendidikan dan pengalaman kerja terhadap kinerja secara total (seluruh unsur) digunakan rumus sebagai berikut: Umar (2000)

- $\quad$ Skor terendah $=$ Bobot terendah X jumlah sampel

- $\quad$ Skor tertinggi $=$ Bobot tertinggi $\mathrm{X}$ jumlah sampel

Analisis deskriptif ini bertujuan untuk mendeskripsikan atau menggambarkan suatu data dalam variabel yang dilihat dari nilai rata-rata (mean), minimum, maksimum, dan standar deviasi (Ghozali, 2009).

\section{Regresi Linier Berganda}

Analisis regresi linier berganda digunakan untuk mengukur kekuatan hubungan antara dua variabel atau lebih, juga menunjukkan arah hubungan antara variabel dependen dengan variabel independen. Persamaan regresi linier berganda yang digunakan dalam penelitian ini dirumuskan sebagai berikut: (Syekh, 2011)

$y=\alpha+b_{1} X_{1}+b_{2} X_{2}+e$

Keterangan: $\mathrm{Y}=$ Kinerja Pegawai; $\mathrm{a}=$ nilai konstanta; $\mathrm{b}=$ koefisien regresi; $\mathrm{X} 1=$ Motivasi; $\mathrm{X} 2=$ Kemampuan; e = Faktor Eror

\section{Uji Hipotesis}

Uji Statistik $F$

Uji $\mathrm{F}$ digunakan untuk menentukan apakah variabel bebas pendidikan $\left(\mathrm{X}_{1}\right)$, pengalaman kerja $\left(\mathrm{X}_{2}\right)$ berpengaruh secara simultan terhadap variabel kinerja (Y). Rumus yang digunakan adalah :

1. Rumus Hipotesis

Ho : tidak ada pengaruh siginifikan (nyata) pendidikan $\left(\mathrm{X}_{1}\right)$, pengalaman kerja $\left(\mathrm{X}_{2}\right)$ secara simultan terhadap variabel terikat kinerja (Y)

$\mathrm{Ha}$ : ada pengaruh signifikan (nyata) pendidikan $\left(\mathrm{X}_{1}\right)$, pengalaman kerja $\left(\mathrm{X}_{2}\right)$ berpengaruh secara simultan terhadap variabel terikat kinerja $(\mathrm{Y})$

2. Tentukan tingkat signifikan dengan $a=5 \%$

3. Kriteria keputusan

Jika $F_{\text {hitung }} \geq F_{\text {tabel }}$ artinya Ho ditolak artinya terdapat pengaruh antara pendidikan $\left(\mathrm{X}_{1}\right)$, pengalaman kerja $\left(\mathrm{X}_{2}\right)$ terhadap kinerja pegawai $(\mathrm{Y})$

Jika $F_{\text {hitung }}<\mathrm{F}_{\text {tabel }}$ artinya Ho diterima artinya tidak terdapat pengaruh antara pendidikan $\left(\mathrm{X}_{1}\right)$, pengalaman kerja $\left(\mathrm{X}_{2}\right)$ terhadap kinerja pegawai $(\mathrm{Y})$

\section{Uji Statistikt}

Uji t digunakan untuk menentukan apakah variabel bebas pendidikan $\left(\mathrm{X}_{1}\right)$, pengalaman kerja $\left(\mathrm{X}_{2}\right)$ berpengaruh secara parsial terhadap variabel kinerja (Y). Rumus yang digunakan adalah:

1. Rumus Hipotesis

Ho : tidak ada pengaruh siginifikan (nyata) pendidikan $\left(\mathrm{X}_{1}\right)$, pengalaman kerja $\left(\mathrm{X}_{2}\right)$ berpengaruh secara parsial terhadap variabel terikat kinerja (Y)

$\mathrm{Ha}$ : ada pengaruh signifikan (nyata) pendidikan $\left(\mathrm{X}_{1}\right)$, pengalaman kerja $\left(\mathrm{X}_{2}\right)$ terhadap variabel terikat kinerja (Y)

2. Tentukan tingkat signifikan dengan $a=5 \%$

3. Kriteria keputusan

Jika $t_{\text {hitung }} \geq t_{\text {tabel }}$ artinya Ho ditolak yang berarti terdapat Pengaruh antara pendidikan $\left(\mathrm{X}_{1}\right)$, pengalaman kerja $\left(\mathrm{X}_{2}\right)$ terhadap kinerja pegawai $(\mathrm{Y})$ 
Jika $t_{\text {hitung }}<\mathrm{t}_{\text {tabel }}$ Ho diterima artinya tidak terdapat Pengaruh sinifikan antara pendidikan $\left(\mathrm{X}_{1}\right)$ dan pengalaman kerja $\left(\mathrm{X}_{2}\right)$ terhadap kinerja pegawai $(\mathrm{Y})$

\section{Uji Beda/Komparatif}

Menurut Syekh (2011) Analisis komparatif atau analisis komparasi atau analisis perbedaan adalah bentuk analisis variabel (data) untuk mengetahui perbedaan diantara dua kelompok data variabel atau lebih.

\section{Uji Koefisien Determinasi $\left(R^{2}\right)$}

Uji $\mathrm{R}^{2}$ atau uji determinasi merupakan suatu ukuran yang penting dalam regresi, karna dapat menginformasikan baik atau tidaknya model regresi yang terestimasi atau dengan kata lain angka tersebut dapat mengukur seberapa dekatkah garis regresi yang terstimasi dengan data sesungguhnya.

\section{HASIL DAN PEMBAHASAN \\ Pengujian Asumsi Klasik \\ Uji Normalitas}

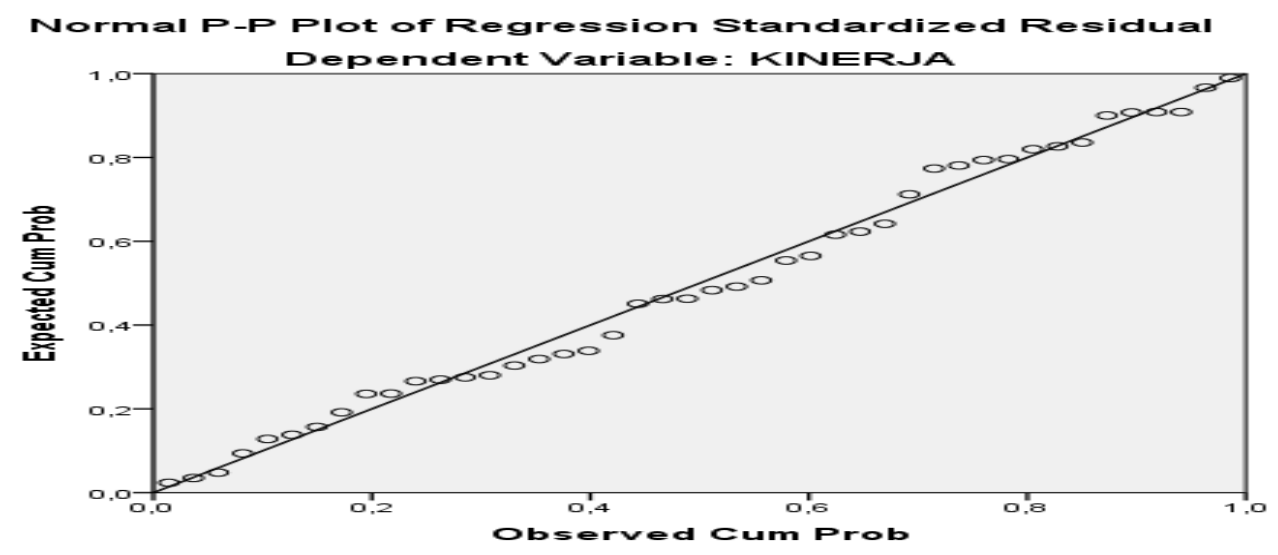

Gambar 2

Uji Normalitas

Berdasarkan hasil uji normalitas dapat dilihat dari Gambar 2 diatas (Normal P-Plot of Regression Standardized Residual) terlihat bahwa titik-titik menyebar di sekitar garis diagonal, serta penyebarannya mengikuti garis diagonal. Hal ini menunjukan bahwa model regresi layak dipakai karena memenuhi asumsi normalitas data berdistribusi normal, karena titik dalam gambar menyebar di sekitar garis diagonal dan arahnya mengikuti garis diagonal.

\section{Uji Heteroskesdastisitas}

Hasil pengujian scatterplot pada gambar 4.2 dapat dilihat bahwa tidak ada pola yang jelas dan titiktitik menyebar antara di bawah 0 sampai di atas 0 pada sumbu Y. oleh karena itu dapat disimpulkan bahwa variabel independen yaitu asimetri informasi dan ukuran perusahaan dalam penelitian ini tidak terjadi heteroskedasitas. 


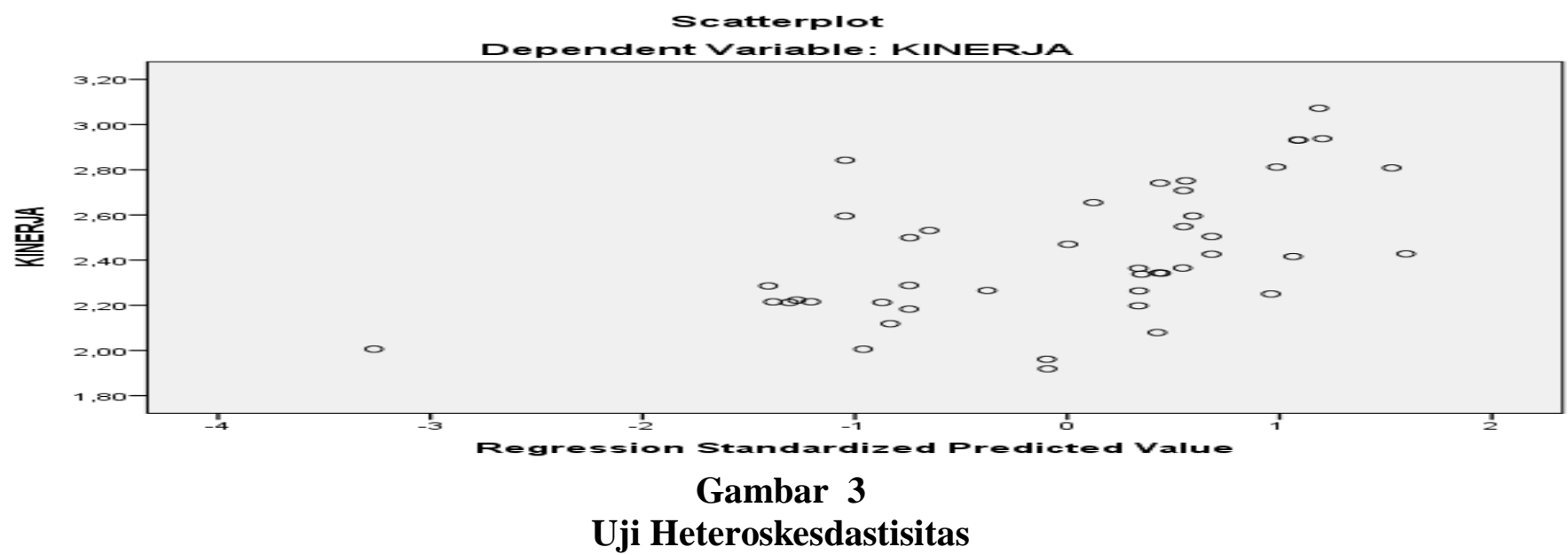

\section{Uji Multikolinearitas}

Multikolinearitas merupakan fenomena adanya korelasi yang sempurna antara satu variabel bebas dalam suatu model regresi linear berganda. Berdasarkan hasil uji multikolinearitas dapat diketahui bahwa nilai VIF dari variabel independen yaitu pendidikan dan pengalaman kerja sebesar 1,013 menunjukan nilai tidak lebih dari 10. Oleh karena itu dapat disimpulkan bahwa tidak ada multikolinearitas antara variabel independen dalam model regresi.

\section{Uji Autokorelasi}

Uji Autokorelasi digunakan untuk melihat apakah pengaruh berdasarkan variabel-variabel dalam modelnya melalui selang waktu, untuk mengetahui apakah terdapat autokorelasi atau tidak. Hasil uji dapat diketahui nilai DW adalah sebesar 0,431 ini berarti dengan melihat kriteria pengambilan keputusan, maka dapat disimpulkan dalam model regresi terjadi autokorelasi positif karena nilainya berada kurang dari 2.

\section{Persamaan Regresi Linear Berganda}

Berdasarkan keterangan diatas diketahui persamaan regresinya adalah sebagai berikut : $\mathrm{Y}=1,810-0,065 \mathrm{X} 1+0,372 \mathrm{X} 2$

Persamaan regresi tersebut diatas dapat dikatakan bahwa koefisien regresi berganda variabel Pendidikan dan Pengalaman Kerja mempunyai arah positif terhadap Kinerja Pegawai pada kantor Camat Tungkal Ilir Kab. Tanjab Barat.

1. $\mathrm{a}=$ konstanta sebesar 1,810 , artinya apabila variabel independen yaitu pendidikan dan pengalaman kerja dianggap konstan (bernilai 0), maka variabel dependen yaitu kinerja pegawai akan mengalami kenaikan sebesar 1,810 .

2. Pendidikan sebesar $-0,065$, artinya apabila variabel pendidikan mengalami kenaikan sebesar 1 (satu) satuan sedangkan variabel lainnya dianggap konstan, maka variabel dependen yaitu kinerja pegawaiakan mengalami penurunan sebesar 0,065 .

3. Ukuran perusahaan sebesar 0,372 , artinya apabila variabel pengalaman kerja mengalami kenaikan sebesar 1 (satu) satuan sedangkan variabel lainnya dianggap konstan, maka variabel dependen yaitu kinerja pegawai akan mengalami kenaikan sebesar 0,372 .

\section{Uji F}

Uji f dilakukan untuk mengetahui pengaruh keseluruhan atau secara simultan variabel independen (pendidikan) dan (pengalaman kerja) terhadap variabel dependen (kinerja pegawai). Pengujian melalui uji $\mathrm{f}$ pada taraf nyata $\alpha=0,05$. Berdasarkan hasil perhitungan diperoleh angka fhitung 8,513 sedangkan ftabel 3,23. Jadi fhitung 8,513> ttabel 3,23, maka keputusannya Ho ditolak dan H1 diterima. Dengan demikian ada pengaruh signifikan antara pendidikan dan pengalaman kerja terhadap kinerja pegawai pada Kantor Camat Tungkal Ilir. Dengan kata lain pendidikan dan pengalaman kerja dapat dijadikan alat untuk memprediksikinerja pegawai pada Kantor Camat Tungkal Ilir. 


\section{Uji t}

Uji t dilakukan untuk mengetahui pengaruh masing-masing atau secara parsial variabel independen (pendidikan) dan (pengalaman kerja) terhadap variabel dependen (kinerja pegawai). Pengujian melalui uji $t$ pada taraf nyata $\alpha=0,05$. Berdasarkan hasil perhitungan diperoleh angka thitung untuk variabel pedidikan2,368 dan thitung untuk variabel pengalaman kerja 3,626 sedangkan ttabel 2,019. Jadi thitung 2,368> ttabel 2,019 untuk varibel pendidikan, maka keputusannya Ho ditolak dan H1 diterima, dengan demikian ada pengaruh signifikan antara pendidikan terhadap kinerja pegawai kantor Camat Tungkal Ilir Kab. Tanjab Barat. Dan $t_{\text {hitung }}$ 3,626 $>t_{\text {tabel }}$ 2,019 untuk variabel pengalaman kerja, maka keputusannya Ho ditolak dan H1 diterima. Dengan demikian ada pengaruh signifikan antara pengalaman kerja terhadap kinerja pegawai kantor Camat Tungkal Ilir Kab. Tanjab Barat. Dengan kata lain pendidikan dan pengalaman kerja dapat dijadikan alat untuk memprediksi kinerja pegawai kantor Camat Tungkal Ilir Kab. Tanjab Barat.

\section{Uji Beda/Komparatif}

Uji beda/komparatif dilakukan untuk mengetahui perbedaan antara sebelum dan sesudah berdasarkan pengalaman kerja pegawai. Oleh karena thitung $(9,261)>t_{\text {tabel }}(2,019)$ maka $\mathrm{H}_{0}$ ditolak dan $\mathrm{H}_{1}$ diterima, artinya terjadi peningkatan kinerja pegawai setelahmemiliki pengalaman kerja berdasarkan data sebelum dan sesudah.

\section{Korelasi}

Korelasi digunakan untuk mengukur hubungan atau keeratan antara variabel satu dengan variabel lainnya. Berdasarkan hasil pengujian koefisien korelasi, menunjukkan bahwa nilai Rsebesar 0,542 menjelaskan bahwa tingkat hubungan antara variabel independen yaitu pendidikan dan pengalaman kerja dengan variabel dependen yaitu kinerja pegawai bersadarkan kriteria koefisien korelasi memiliki hubungan korelasi yang tergolong sedang.

\section{Koefisien Determinasi $\left(R^{2}\right)$}

Hasil perhitungan SPSS untuk melihat koefisien korelasi. Hasil pengujian determinasi maka diperoleh nilai $R^{2}$ sebesar 0,293 angka ini menyatakan bahwa variabel X1 atau pendidikan dan X2 atau pengalaman kerja mampu menjelaskan variabel Y atau kinerja pegawai pada kantor Camat Tungkal Ilir Kab. Tanjab Barat sebesar 29,3\% sisanya 70,7\% disebabkan oleh variabel lain diluar variabel yang diteliti.

\section{Analisis Pengaruh Pendidikan dan Pengalaman Kerja Terhadap Kinerja Pegawai di Kantor Camat Tungkal Ilir.}

Pendidikan dan Pengalaman Kerja berpengaruh signifikan terhadap Kinerja Pegawai pada Kantor Camat Tungkal Ilir. Hal ini dapat ditunjukkan nilai $\mathrm{f}_{\text {hitungsebesar }}$ 8,513 sedangkan $\mathrm{f}_{\text {tabel }}$ sebesar 3,23 maka dapat dikatakan pendidikan dan pengalaman kerja berpengaruh signifikan secara simultan terhadap kinerja pagawai. Sedangkan $t_{\text {hitung }}$ untuk pendidikan sebesar 2,368 dan nilai $t_{\text {tabel }}$ 2,019 dari hasil perbandingan maka dapat diketahui bahwa thitung 2,368> ttabel2,019, maka keputusannya Ho ditolak dan H1 diterima. Dengan demikian ada pengaruh signifikan antara pendidikan terhadap kinerja pegawai pada Kantor Camat Tungkal Ilir. Dan $t_{\text {hitung }}$ untuk pengalaman kerja sebesar 3,626 dan nilai $t_{\text {tabel }}$ 2,019 dari hasil perbandingan maka dapat diketahui bahwa thitung 3,626> ttabel2,019, maka keputusannya Ho ditolak dan H1 diterima. Dengan demikian ada pengaruh signifikan antara pengalaman kerja terhadap kinerja pegawai pada Kantor Camat Tungkal Ilir. Uji beda dalam penelitian ini yaitu $t_{\text {hitung }}(9,261)>t_{\text {tabel }}(2,019)$ maka $\mathrm{H}_{0}$ ditolak dan $\mathrm{H}_{1}$ diterima, artinya terjadi peningkatan kinerja pegawai setelah memiliki pengalaman kerja. Berdasarkan hasil pengujian koefisien korelasi, menunjukkan bahwa nilai Rsebesar 0,542 menjelaskan bahwa tingkat hubungan antara variabel independen yaitu pendidikan dan pengalaman kerja dengan variabel dependen yaitu kinerja pegawai bersadarkan kriteria koefisien korelasi memiliki hubungan korelasi yang tergolong sedang. Dari hasil pengujian determinasi maka diperoleh nilai $R^{2}$ sebesar 0,293 angka ini menyatakan bahwa variabel X1 atau pendidikan dan X2 atau pengalaman kerja mampu menjelaskan variabel $\mathrm{Y}$ atau kinerja pegawai pada kantor Camat Tungkal Ilir Kab. Tanjab Barat sebesar 29,3\% sisanya 70,7\% disebabkan oleh variabel lain diluar variabel yang diteliti. 


\section{Saiyid Syekh}

\section{SIMPULAN}

1. Hasil deskriftif berdasarkan jawaban respon dari kuesioner tentang indikator Pendidikan berdasarkan rata-rata skor keseluruhan sebesar 183,66 dengan keterangan pendidikan pegawai di kantor Camat Tinggi. Tentang indikator Pengalaman Kerja berdasarkan rata-rata skor keseluruhan sebesar 172,33 dengan keterangan berpengalaman. indikator Kinerja pegawai di kantor Camat berdasarkan jawaban responden dengan total keseluruhan sebesar 173,42 dengan keterangan kinerja pegawai di kantor Camat Tinggi.

2. Hasil pengujian secara simultan dapatdilihat hasil perbandingan antara $f_{\text {hitung }}$ dan $f_{\text {tabel }}$ yang menunjukan

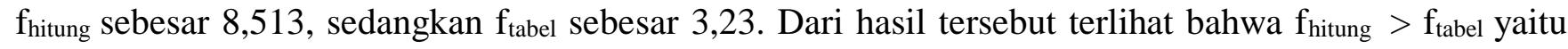
$8,513>3,23$

3. Hasil pengujian pada model regresi secara parsial, dapat dilihat hasil perbandingan antara $t_{\text {hitung }}$ dan $t_{\text {tabel }}$ yang menunjukan $t_{\text {hitung }}$ sebesar 2,368, sedangkan $t_{\text {tabel }}$ sebesar 2,019. Dari hasil tersebut terlihat bahwa $t_{\text {hitung }}<t_{\text {tabel }}$ yaitu $2,368<2,019$

\section{DAFTAR PUSTAKA}

Adisetiawan, R., 2017, Performance Mahasiswa Fakultas Ekonomi Universitas Batanghari, Jurnal Ilmiah Universitas Batanghari, 14(3), 1-10

Adisetiawan, R., 2016, Faktor yang Mempengaruhi Lulusan SMA dalam Memilih Fakultas Ekonomi

Universitas Batanghari, Jurnal Ilmiah Universitas Batanghari, 16(3), 1-11

Departemen pendidikan. 2005. Kamus Besar Bahasa Indonesia. Edisi ke-3, Balai pustaka, Jakarta

Foster, Bill. 2001. Pembinaan untuk peningkatan kinerja karyawan. PPM, Jakarta.

Ghozali, Imam. 2009. Aplikasi Analisis Multivariate dengan Program SPSS. UNDIP, Semarang.

Husein, Umar. 2000. Riset Sumber Daya Manusia. Gramedia Pustaka Utama, Jakarta.

Kaswan. 2012. Manajemen Sumber Daya Manusia Untuk Keunggulan Bersaing Organisasi. Graha Ilmu, Yogyakarta.

Rivai, Veithizal. 2004. Performance Appraisal : System Yang Tepat Untuk Menilai Kinerja Karyawan dan Meningkatkan Daya Saing Perusahaan. Edisi 1. PT. Raja Grafindo Persada, Jakarta.

Sudirman S., dan Alhudhori, M., 2018, Pengaruh Konsumsi Rumah Tangga, Investasi Terhadap Pertumbuhan Ekonomi di Provinsi Jambi, Ekonomis: Journal Economics and Business, 2(1), 81-91

Syekh. 2011. Pengantar Statistik Ekonomi Dan Sosial, PT. Gaung Persada, Jakarta.

Tirtarahardja, Umar. 2005. Pengantar Pendidikan. Rineka Cipta, Jakarta. 